\title{
Mass balance-based plant-wide wastewater treatment plant models - Part 3: Biodegradability of activated sludge organics under anaerobic conditions
}

\author{
GA Ekama*, SW Sötemann and MC Wentzel
}

Water Research Group, Department of Civil Engineering, University of Cape Town, Rondebosch 7701, Cape, South Africa

\begin{abstract}
From an experimental and theoretical investigation of the continuity of activated sludge organic (COD), inorganic and $\mathrm{N}$ compounds along the link between the fully aerobic or $\mathrm{N}$ removal activated sludge (AS) and anaerobic digestion unit operations, it was found that the unbiodegradable particulate organics originating from the influent wastewater and generated by the activated sludge endogenous process, as determined from the response of the activated sludge system, are also unbiodegradable under anaerobic digestion conditions. This means that the activated sludge biodegradable organics that can be anaerobically digested can be calculated from the active fraction of the waste activated sludge with the well-established stoichiometric and kinetic constants in steady state and dynamic simulation models. This research shows that the mass balance-based steady state activated sludge, aerobic digestion and anaerobic digestion models provide internally consistent and externally compatible elements that can be coupled to produce plant-wide steady state and dynamic simulation WWTP models.
\end{abstract}

Keywords: wastewater treatment, activated sludge, biodegradability, anaerobic digestion, model validation

\section{List of abbreviations}

AD anaerobic digestion

ADM1 Anaerobic Digestion Model No. 1

AerD aerobic digestion

Alk alkalinity with respect to the $\mathrm{H}_{2} \mathrm{CO}_{3} *$ reference species

ADWF average dry weather flow

AS activated sludge

ASM1,2,3 Activated Sludge Models No. 1, 2 or 3

BEPR biological excess phosphorus removal

BNR biological nutrient removal

$\mathrm{C}$ carbon

${ }^{\circ} \mathrm{C} \quad$ degrees Centigrade

$\mathrm{Ca} \quad$ calcium

COD chemical oxygen demand

d day

$\mathrm{Eq} \quad$ equation

FSA free and saline ammonia

$\mathrm{H}$ hydrogen

ISS inert suspended solids

$\mathrm{K}$ potassium

$\ell \quad$ litres

$\mathrm{Mg} \quad$ magnesium

$\mathrm{N} \quad$ nitrogen

ND nitrifying - denitrifying

NDBEPR nitrifying - denitrifying biological excess

$\mathrm{OHO} \quad$ ordinary heterotrophic organism

$\mathrm{OP}$ phosphorus removal

$\mathrm{O} \quad$ oxygen

\begin{tabular}{|c|c|}
\hline OrgN & organic nitrogen \\
\hline OTR & oxygen transfer rate \\
\hline OUR & $\begin{array}{l}\text { oxygen utilisation rate, subscripts } \mathrm{c}, \mathrm{n} \text { and } \mathrm{t} \text { denote } \\
\text { carbonaceous, nitrification and total }\end{array}$ \\
\hline $\mathrm{P}$ & phosphorus \\
\hline PAO & phosphorus accumulating organism \\
\hline pH & negative log of the hydrogen ion activity \\
\hline PS & primary sludge \\
\hline PST & primary settling tank \\
\hline Q & flow \\
\hline $\mathrm{R}$ & $\begin{array}{l}\text { hydraulic retention time or sludge age for anaerobic } \\
\text { digester }\end{array}$ \\
\hline RBCOD & readily biodegradable COD \\
\hline SBCOD & slowly biodegradable COD \\
\hline SOUR & $\begin{array}{l}\text { specific oxygen utilisation rate }(\mathrm{mgO} /(\mathrm{gVSS} . \mathrm{d}) \text {. } \\
\text { Subscripts } \mathrm{c}, \mathrm{n} \text { and } \mathrm{t} \text { denote carbonaceous, nitrifica- } \\
\text { tion and total. }\end{array}$ \\
\hline SS & settleable solids \\
\hline TKN & total Kjeldahl nitrogen \\
\hline ТP & total phosphorus \\
\hline TSS & total suspended solids \\
\hline V & volume \\
\hline VFA & volatile fatty acids \\
\hline VSS & volatile suspended solids \\
\hline VS & volatile solids \\
\hline WAS & waste activated sludge \\
\hline WW & wastewater \\
\hline WWTP & wastewater treatment plant \\
\hline
\end{tabular}

\section{List of symbols}

$b_{H}, b_{H}^{\prime}$

OHO endogenous respiration and death rates (/d). Additional subscripts $\mathrm{T}$ and 20 denote rates at $\mathrm{T}$ and $20^{\circ} \mathrm{C}$

* To whom all correspondence should be addressed. 뚐 +2721 650 2588; fax: +27 21689 7471; OHO fraction of AS with respect to VSS and TSS. Additional subscripts i or e denote aerobic digester influent or effluent. 


\begin{tabular}{|c|c|}
\hline & Carbon to VSS ratio of particulate organics \\
\hline & $\mathrm{COD} / \mathrm{VSS}$ ratio of $\mathrm{AS}$ and PS \\
\hline & $\begin{array}{l}\text { unbiodegradable fraction of OHOs in endogenous } \\
\text { respiration and death regeneration models }\end{array}$ \\
\hline$f_{i}, f_{i i}, f_{i e}$ & $\begin{array}{l}\text { VSS/TSS ratio of AS. Subscripts i and e denote } \\
\text { influent and effluent sludge. Subscript PS refers to } \\
\text { primary sludge. }\end{array}$ \\
\hline & Inorganic content of OHOs (mgISS/mgOHOVSS) \\
\hline & Nitrogen fraction of AS and PS (mgN/mgVSS) \\
\hline & Fraction of influent TKN that is FSA \\
\hline & $\begin{array}{l}\text { Fraction of influent TKN that is unbiodegradable } \\
\text { soluble OrgN }\end{array}$ \\
\hline & Fraction of COD removed by primary sedimentation \\
\hline & Phosphorus fraction of AS (mgP/mgVSS). \\
\hline & Additional subscript PS denotes primary sludge \\
\hline & Fraction of unbiodegradable COD in AS and PS \\
\hline & $\begin{array}{l}\text { Influent RBCOD fraction with respect to the } \\
\text { biodegradable COD }\end{array}$ \\
\hline$f_{S^{\prime} u p^{\prime}} f_{S^{\prime} u s}$ & $\begin{array}{l}\text { Particulate and soluble unbiodegradable COD } \\
\text { fraction of wastewater. }\end{array}$ \\
\hline & $\begin{array}{l}\text { Additional subscript } \mathrm{R} \text { and } \mathrm{S} \text { denote raw and settled } \\
\text { wastewater. }\end{array}$ \\
\hline$f_{v s r^{\prime}} f_{t s r}$ & $\begin{array}{l}\text { Fraction of VSS and TSS removed in aerobic } \\
\text { digestion. }\end{array}$ \\
\hline & $\mathrm{P}$ content of PAOs (mgP/mgPAOVSS) \\
\hline$f_{Z B, N}$ & ntent of OHOs (mgN or mgP per \\
\hline$N_{a i}$ & Influent ammonia (FSA) concentration (mgN/l) \\
\hline$N_{o b p i}^{a i}, N_{o b s i}$ & $\begin{array}{l}\text { Influent biodegradable particulate and soluble } \\
\text { OrgN concentration }(\mathrm{mgN} / \mathrm{l})\end{array}$ \\
\hline$N_{\text {oupi }}, N_{\text {ousi }}$ & $\begin{array}{l}\text { Influent unbiodegradable particulate and soluble } \\
\text { OrgN concentration }(\mathrm{mgN} / \mathrm{l})\end{array}$ \\
\hline$O$ & $\begin{array}{l}\text { Oxygen utilisation rate }[\mathrm{mgO} /(\ell \cdot h)] \text {. Subscripts } \mathrm{c}, \mathrm{n} \\
\text { and } \mathrm{t} \text { denote carbonaceous, nitrification and total }\end{array}$ \\
\hline$p_{\mathrm{CO} 2}$ & Partial pressure of $\mathrm{CO}_{2}$ \\
\hline$Q_{i}$ & Influent flow $(\ell / d)$ \\
\hline$R_{h}$ & Hydraulic retention time $(\mathrm{d})$ \\
\hline$R_{s}$ & Sludge age $(d)$ \\
\hline$R^{s}$ & Correlation coefficient \\
\hline$S_{b p}$ & $\begin{array}{l}\text { Biodegradable particulate organics concentration } \\
(\mathrm{mgCOD} / \ell)\end{array}$ \\
\hline$S_{b p i}, S_{b s i}$ & $\begin{array}{l}\text { Influent biodegradable particulate and soluble COD } \\
\text { concentrations }(\mathrm{mgCOD} / \ell)\end{array}$ \\
\hline$S_{t i}, S_{t e}$ & $\begin{array}{l}\text { Total influent and effluent COD concentration } \\
(\mathrm{mgCOD} / \ell)\end{array}$ \\
\hline$S_{u p i} S_{u s i}$ & $\begin{array}{l}\text { Influent unbiodegradable particulate and soluble } \\
\text { COD concentrations }(\operatorname{mgCOD} / \ell)\end{array}$ \\
\hline$V_{d}$ & Volume of digester \\
\hline$X_{B H}^{d}$ & OHO biomass concentration (mgVSS/l) \\
\hline & OHO endogenous residue concentration (mgVSS/l) \\
\hline$X_{p}, X_{I i}$ & $\begin{array}{l}\text { Unbiodegradable organics concentration in reactor } \\
\text { (mgVSS/l). Additional subscript } i \text { denotes influent. }\end{array}$ \\
\hline$X_{I o}, X_{I o i}$ & $\begin{array}{l}\text { ISS (fixed and biomass) concentration in reactor } \\
\text { (mgISS/ } / \text { ). Additional subscript } i \text { denotes influent. }\end{array}$ \\
\hline$X_{v}, X_{v i}, X_{v e}$ & $\begin{array}{l}\text { VSS concentration }(\mathrm{mgVSS} / \ell) \text {. Additional subscript } \\
\mathrm{i} \text { and e denote influent and effluent. }\end{array}$ \\
\hline$X_{t}, X_{t i}, X_{t e}$ & $\begin{array}{l}\text { TSS concentration (mgTSS } / \ell \text { ). Additional subscript } \\
i \text { and e denote influent and effluent. }\end{array}$ \\
\hline$Y_{H}$ & OHO yield coefficient (mgVSS/mgCOD) \\
\hline$\alpha, \beta, \gamma, \delta$ & $\begin{array}{l}\text { substitution variables in VSS and TSS based steady } \\
\text { state AerD model }\end{array}$ \\
\hline 4.57 & mgO required per mgFSA-N nitrified to nitrate \\
\hline
\end{tabular}

$f_{c} \quad$ Carbon to VSS ratio of particulate organics

$f_{E H} f_{E H}^{\prime} \quad$ unbiodegradable fraction of OHOs in endogenous respiration and death regeneration models

influent and effluent sludge. Subscript PS refers to primary sludge.

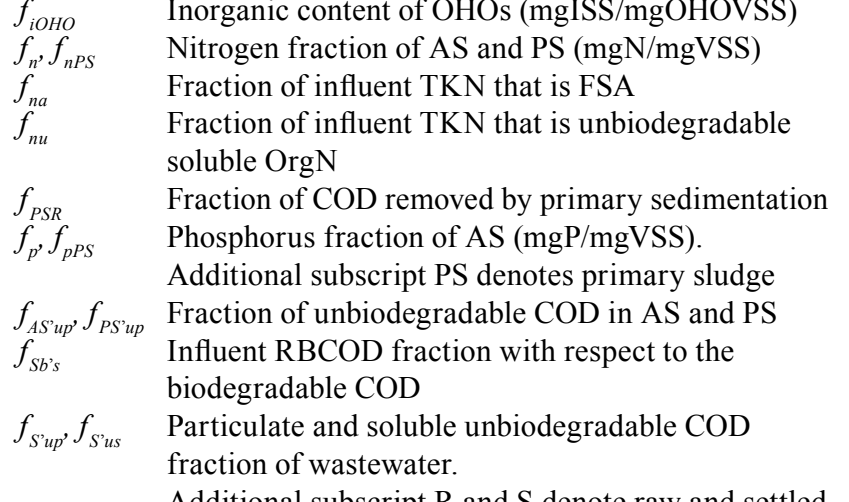

wastewater.

$\begin{array}{ll} & \text { digestion. } \\ f_{X B G P} & \text { P content of PAOs (mgP/mgPAOVSS) }\end{array}$

$f_{Z B, N} f_{Z B, P} \quad \mathrm{~N}$ and $\mathrm{P}$ content of OHOs (mgN or mgP per

$\begin{array}{ll}N_{a i} & \text { Influent ammonia (FSA) concentration (mgN/l) }\end{array}$

$N_{\text {obpi }}, N_{\text {obsi }}$ Influent biodegradable particulate and soluble

OrgN concentration (mgN/l)

OrgN concentration (mgN/l)

Oxygen utilisation rate $[\mathrm{mgO} /(\ell \cdot h)]$. Subscripts $\mathrm{c}, \mathrm{n}$ and $t$ denote carbonaceous, nitrification and total

\section{Introduction}

In developing steady state and dynamic simulation materials mass balance-based models for plant-wide wastewater treatment plant (WWTPs) models, the previous two papers of this series considered the biodegradability under anaerobic conditions of influent wastewater particulate organics that settle out as primary sludge, and whether this matches the biodegradablibity of these organics as determined by the aerobic activated sludge (AS) system (Wentzel et al., 2006, Part 1), and the conservation of influent wastewater inorganic suspended solids (ISS) through the primary sludge (PS) anaerobic digester (AD), the AS system and the waste activated sludge (WAS) aerobic digester (Ekama et al., 2006, Part 2). This paper focuses on the AS system - AD link and considers the biodegradability of the WAS organics and the fate of the influent wastewater ISS under anaerobic conditions. Two sets of literature data, viz. Gossett and Belser (1982) and Van Haandel et al. (1998a,b) and one set of author data are investigated. Only fully aerobic or $\mathrm{N}$ removal activated sludge systems, in which mineral precipitation under anaerobic conditions is unlikely, are considered in this paper. Anaerobic digestion of WAS with phosphorus accumulating organisms (PAOs) from enhanced biological excess phosphorus removal plants will be considered in further research.

\section{Gossett and Belser (1982) data}

Gossett and Belser (1982) operated at $20^{\circ} \mathrm{C}$ six fully aerobic $2 \mathrm{~d}$ retention time AS systems at 5, 10, 15, 20, 25 and $30 \mathrm{~d}$ sludge age, each fed a synthetic wastewater made from glucose, acetate and peptone. The WAS from each system was fed to six flow-though methanogenic $\left(35^{\circ} \mathrm{C}\right)$ anaerobic digesters at $15 \mathrm{~d}$ retention time. Once steady state conditions were achieved ( $>3$ sludge ages), influent and effluent COD and VSS concentrations and reactor OUR and VSS concentrations were measured on the AS systems and influent and effluent COD and VSS concentrations and methane production and gas composition were measured on the AD systems. The AS endogenous respiration rate $\left(b_{\mathrm{H} 20}\right)$ was determined in aerobic batch tests on blended sludge harvested from the AS systems and a rate of $0.0956 / \mathrm{d}$ was obtained. Also, batches of sludge harvested from the six ADs were placed in sealed containers and the cumulative methane production and final VSS concentration measured over a further $113 \mathrm{~d}$. The COD balances in the continuous and batch ADs calculated from the data given ranged between 89 and 101\% (average $95 \%$ ) and 97 and 101\% (average 98\%) respectively. Because only the specific [SOUR, $\mathrm{mgO} /(\mathrm{gVSS} \cdot \mathrm{min})]$ data are given for the AS systems, the COD balances on these systems could not be checked.

From a combination of the Christensen and McCarty (1975) and McKinney (1962) steady state AS models (which together is identical to that of Marais and Ekama, 1976) and the measured $b_{H}$ value, the unbiodegradable fraction of the WAS $\left(f_{E H}\right)$ was determined, viz. 0.317. Then with the McCarty (1974) steady state AD model in which the methane production plus $\mathrm{AD}$ biomass generation (which is negligible at long $\mathrm{AD}$ retention times) is equal to the COD removal, the theoretical and measured cumulative methane productions were equated for the long retention time batch ADs. The $\mathrm{f}_{\mathrm{EH}}$ so obtained was close to that determined from the AS systems. The continuous AD data could not be used for $\mathrm{f}_{\mathrm{EH}}$ determination because at $15 \mathrm{~d}$ retention time the biodegradable organics in the WAS were not all utilised. From the results, Gossett and Belser (1982) concluded that the unbiodegradable organics (endogenous residue) in WAS, as 
Figure 1

Wastewater treatment plant layout of Van Haandel et al. (1998a,b) comprising an aerated lagoon (RO) and four in series aerobic digesters (R1$R 4$ ), each feeding waste activated sludge to five anaerobic digesters (AD0-AD4). System was sampled at Points $P 1$ to P15.

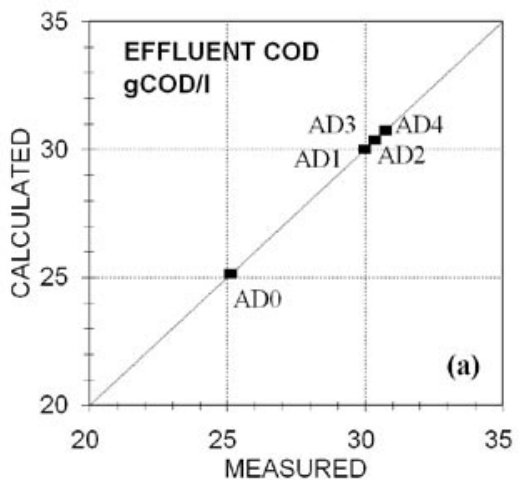

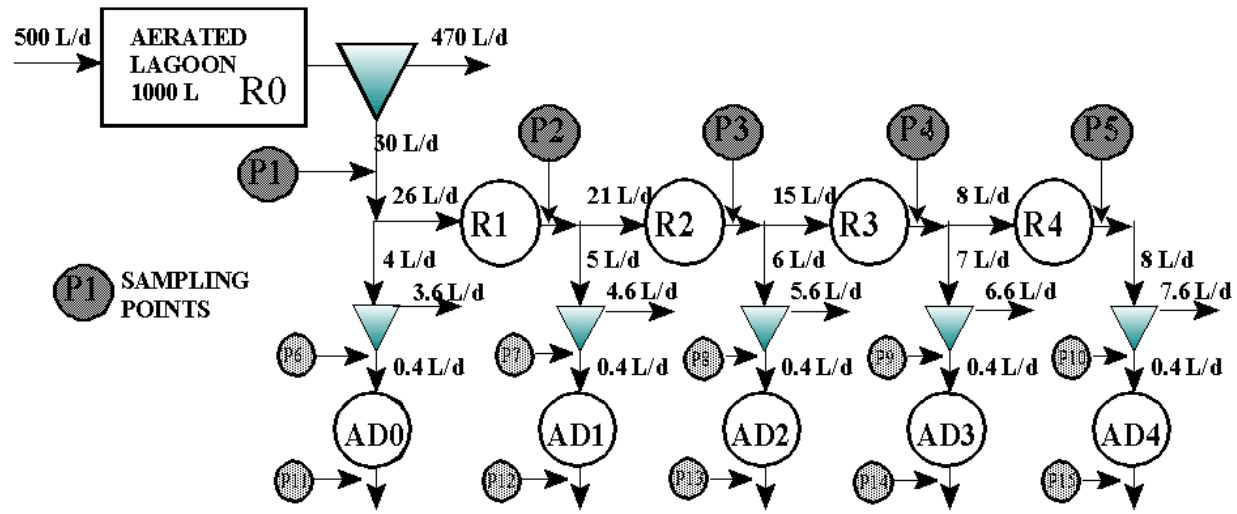
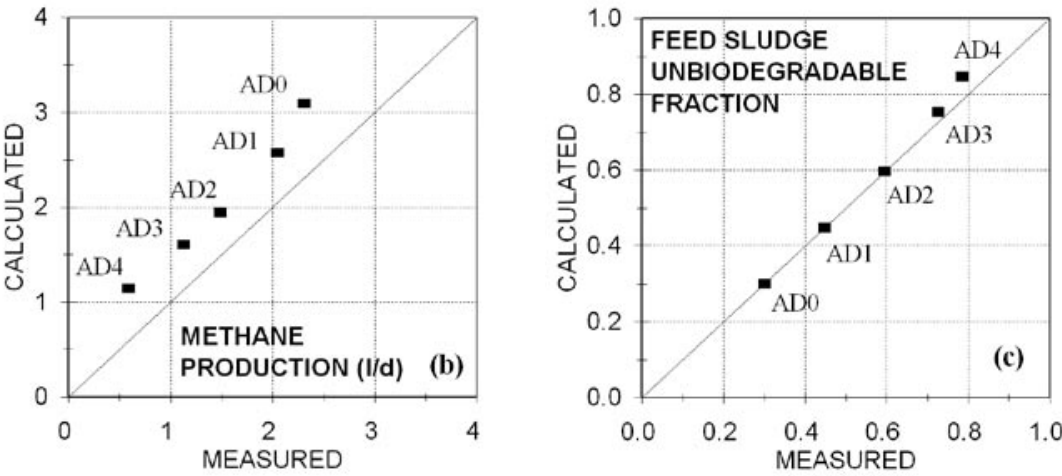

Figure 2

Theoretically calculated with the steady state AD model of Sötemann et al. (2005a) versus experimentally measured effluent $C O D$ concentration (gCOD/l, Fig. 2a top left), methane production ( $\ell / d$, Fig. $2 b$, top right) and feed sludge unbiodegradable COD fraction (fAS'up) (Fig. 2c, bottom left) for the 5 anaerobic digesters (ADO to AD4) of Van Haandel et al. (1998b) fed waste activate sludge with decreasing active fraction from a series of aerobic digesters ( $R 0$ to $R 4$ ).

determined under aerobic conditions, are also unbiodegradable under anaerobic conditions.

Applying this conclusion in plant-wide WWTP models linking $\mathrm{AS}$ and $\mathrm{AD}$ systems, raises two issues:

- AS models, both steady state and dynamic simulation such as ASM1, 2, 2d and 3 developed from real wastewater experimental data, use ordinary heterotrophic organism $(\mathrm{OHO})$ endogenous respiration $\left(\mathrm{b}_{\mathrm{H}}=0.24 / \mathrm{d}\right)$ or death $\left(\mathrm{b}_{\mathrm{H}}=\right.$ $0.62 / \mathrm{d}$ ) rates that are 2.5 times higher than that measured by Gossett and Belser (1982) (0.0956/d) on the synthetic wastewater AS systems. It was not possible to reconcile these AS model results, with the accepted $b_{\mathrm{H}}$ or $\mathrm{b}_{\mathrm{H}}$ and associated unbiodegradable $\mathrm{OHO}$ fraction values $\left(\mathrm{f}_{\mathrm{EH}}=0.20\right.$ and $\mathrm{f}^{\prime}{ }_{\mathrm{BH}}=0.08$ respectively) with the Gossett and Belser (1982) AS data.

- Because Gossett and Belser (1982) used a synthetic wastewater, the biodegradability of the influent unbiodegradable organics in real wastewater was not tested. Applying AS and AD models to the real wastewater data of van Haandel et al. $(1998 \mathrm{a}, \mathrm{b})$ resolves these issues.

\section{Van Haandel et al. (1998a; b) data}

Van Haandel et al. (1998a,b) operated a pilot-scale wastewater treatment plant scheme at $25^{\circ} \mathrm{C}$ in which $500 \mathrm{l} / \mathrm{d}$ raw municipal wastewater was fed to a $2 \mathrm{~d}$ retention time aerated lagoon (R0). All the daily WAS from the aerated lagoon was thickened into $30 \ell$ which served as feed to a series of four aerobic digesters
(R1 to R4) at retention times of $1.73 \mathrm{~d}, 2.14 \mathrm{~d}, 3.00 \mathrm{~d}$ and $5.63 \mathrm{~d}$ respectively. From the feed to each aerobic digester, 4, 5, 6, 7 and $8 \mathrm{l} / \mathrm{d}$ of sludge volume respectively was withdrawn, thickened to a volume of $0.40 \mathrm{l} / \mathrm{d}$ and fed to five anaerobic digesters (AD0 to AD4) each at $20 \mathrm{~d}$ retention time (Fig. 1). Each AD was therefore fed WAS with a different fraction of unbiodegradable particulate organics depending on the extent of aerobic digestion before anaerobic digestion. The experimental data measured on the effluent sludges from R0 to R4 are listed in Table 1 of Ekama et al. (2006, Part 2). The experimental data measured on the influent and effluent liquors from $\mathrm{AD} 0$ to $\mathrm{AD} 4$ are listed in Table 1 of this paper.

\section{Determining the unbiodegradable COD fraction of WAS - Van Haandel et al. (1998a,b) data}

The COD concentration and unbiodegradable particulate COD fraction $\left(\mathrm{f}_{\mathrm{AS} \text { 'up }}\right)$ calculated from the measured data in the outflow from R0 to R4 was set as input to the steady state AD model of Sötemann et al. (2005a). Because the effluent VSS concentrations (and therefore in effect also the effluent COD concentration through the measured 1.50 COD/VSS ratio) from anaerobic digesters AD0 to AD4 were measured for each digester, the residual (non-anaerobically digested) biodegradable particulate COD concentration $\left(\mathrm{S}_{\mathrm{bp}}\right)$ could be calculated from Eq. $(25)$ in Sötemann et al. (2005a) such that the calculated total effluent COD concentration, which includes also unbiodegradable particulate organics and generated anaerobic biomass, matched 


\begin{tabular}{|c|c|c|c|c|c|c|c|c|c|c|}
\hline \multicolumn{11}{|c|}{$\begin{array}{c}\text { TABLE } 1 \\
\text { Experimentally measured (Van Haandel et al., 1998a,b) and theoretically calculated concentrations in } \\
\text { the outflows from the 2d retention time aerated lagoon (R0) and the four in-series aerobic digesters } \\
\text { (R1-R4) and the inflow and outflows of the five anaerobic digesters AD0 to AD4 respectively. }\end{array}$} \\
\hline Parameter & Ro & AD0 & R1 & AD1 & R2 & AD2 & R3 & AD3 & R4 & AD4 \\
\hline \multirow[t]{2}{*}{ Sample Point } & P6 & P6 & P7 & P7 & P8 & P8 & P9 & P9 & P10 & P10 \\
\hline & $\begin{array}{c}\text { Effl } \\
\text { R0 }\end{array}$ & $\begin{array}{c}\text { Infl } \\
\text { AD0 }\end{array}$ & $\begin{array}{c}\text { Effl } \\
\text { R1 }\end{array}$ & $\begin{array}{c}\text { Infl } \\
\text { AD1 }\end{array}$ & $\begin{array}{l}\text { Effl } \\
\text { R2 }\end{array}$ & $\begin{array}{c}\text { Infl } \\
\text { AD2 }\end{array}$ & $\begin{array}{l}\text { Effl } \\
\text { R3 }\end{array}$ & $\begin{array}{c}\text { Infl } \\
\text { AD3 }\end{array}$ & $\begin{array}{c}\text { Effl } \\
\text { R4 }\end{array}$ & $\begin{array}{c}\text { Infl } \\
\text { AD4 }\end{array}$ \\
\hline \multirow[t]{2}{*}{ Flow $\ell / d$} & 0.40 & 0.40 & 0.40 & 0.40 & 0.40 & 0.40 & 0.40 & 0.40 & 0.40 & 0.40 \\
\hline & Exper & Theory & Exper & Theory & Exper & Theory & Exper & Theory & Exper & Theory \\
\hline \multicolumn{11}{|c|}{ Inflow: Experimentally measured and theoretically predicted characteristics and concentrations } \\
\hline TSS - X $(\mathrm{g} / \ell)$ & 4.20 & 4.24 & 3.74 & 3.51 & 2.91 & 2.95 & 2.51 & 2.54 & 2.11 & 2.24 \\
\hline VSS - X $(g / \ell)$ & 3.01 & 3.01 & 2.52 & 2.40 & 1.89 & 1.93 & 1.57 & 1.58 & 1.26 & 1.33 \\
\hline VSS/TSS $-f_{i}$ & 0.720 & 0.711 & 0.674 & 0.683 & 0.651 & 0.654 & 0.625 & 0.623 & 0.598 & 0.594 \\
\hline $\mathrm{OUR}_{+}-\mathrm{mgO} /(\ell . \mathrm{h})$ & 44 & 43.57 & 29 & 28.94 & 16 & 17.80 & 8 & 9.49 & 4 & 3.59 \\
\hline Active fraction, $\mathrm{f}_{\mathrm{av}}$ & 0.76 & 0.760 & 0.60 & 0.634 & 0.44 & 0.485 & 0.27 & 0.315 & 0.17 & 0.142 \\
\hline Sludge fed to & \multicolumn{2}{|c|}{ AD0 at $4 \ell / d$} & \multicolumn{2}{|c|}{$\mathrm{AD} 1$ at $5 \ell / \mathrm{d}$} & \multicolumn{2}{|c|}{$\mathrm{AD} 2$ at $6 \ell / \mathrm{d}$} & \multicolumn{2}{|c|}{ AD3 at $7 \ell / d$} & \multicolumn{2}{|c|}{ AD4 at $8 \ell / d$} \\
\hline Thickening & \multicolumn{2}{|c|}{$10.0 \mathrm{x}$} & \multicolumn{2}{|c|}{$12.5 \mathrm{x}$} & \multicolumn{2}{|c|}{$15.0 \mathrm{x}$} & \multicolumn{2}{|c|}{$17.5 \mathrm{x}$} & \multicolumn{2}{|c|}{$20.0 \mathrm{x}$} \\
\hline Influent COD (g/l) & 45.37 & 45.16 & 47.25 & 44.94 & 42.75 & 43.40 & 41.25 & 41.46 & 37.87 & 39.96 \\
\hline Infl BioCOD $(\mathrm{g} / \mathrm{l})^{*}$ & 31.76 & 31.56 & 26.05 & 26.21 & 17.27 & 19.35 & 10.15 & 12.03 & 5.81 & 5.20 \\
\hline Unbio frac $\left(f_{A S^{\prime} u}\right)^{*}$ & 0.300 & 0.301 & 0.449 & 0.417 & 0.596 & 0.554 & 0.754 & 0.710 & 0.847 & 0.870 \\
\hline Filtered COD $(\mathrm{mg} / \mathrm{l})$ & 140 & 590 & 150 & 770 & 160 & 700 & 190 & 560 & 130 & 710 \\
\hline VFA $(\mathrm{mgCOD} / \ell)$ & ND & 14 & ND & 18 & ND & 15 & ND & 11 & $\mathrm{ND}$ & 17 \\
\hline TKN (mgN/l) & 3060 & - & 3134 & - & 2838 & - & 2739 & - & 2517 & - \\
\hline FSA (mgN/l) & 75 & 0 & 25 & 0 & 25 & 0 & 25 & 0 & 25 & 0 \\
\hline $\mathrm{Alk}\left(\mathrm{mg} / \mathrm{l} \mathrm{CaCO}_{3}\right)$ & 1075 & - & 800 & - & 550 & - & 375 & - & 250 & - \\
\hline $\mathrm{pH}$ & 7.88 & - & 7.73 & - & 7.51 & - & 7.20 & - & 7.23 & - \\
\hline $\operatorname{VSS}(\mathrm{mgVSS} / \ell)$ & 30.25 & - & 31.50 & - & 28.50 & - & 27.50 & - & 25.25 & - \\
\hline TSS (mgTSS/l) & 42.00 & - & 46.75 & - & 43.75 & - & 44.00 & - & 42.25 & - \\
\hline \multicolumn{11}{|c|}{ Outflow: Experimentally measured and theoretically predicted characteristics and concentrations } \\
\hline $\mathrm{COD}(\mathrm{mgCOD} / \ell)$ & 24.79 & 24.79 & 29.97 & 29.97 & 29.60 & 29.60 & 30.34 & 30.34 & 29.97 & 29.97 \\
\hline VFA (mgCOD/l) & 14 & 0 & 18 & 0 & 15 & 0 & 11 & 0 & 17 & 0 \\
\hline TKN (mgN/l) & 3131 & 3029 & 3122 & 3108 & 2848 & 2817 & 2771 & 2722 & 2472 & 2505 \\
\hline FSA (mgN/l) & 1500 & 1398 & 1150 & 1136 & 900 & 870 & 775 & 726 & 500 & 533 \\
\hline $\mathrm{Alk}\left(\mathrm{mg} / \mathrm{l} \mathrm{CaCO}_{3}\right)$ & 4875 & 5800 & 3600 & 4767 & 3000 & 3569 & 2625 & 2880 & 1400 & 2064 \\
\hline $\mathrm{pH}$ & 7.89 & 7.29 & 7.88 & 7.20 & 7.85 & 7.08 & 7.81 & 6.98 & 7.86 & 6.84 \\
\hline 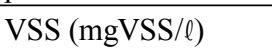 & 16.75 & 16.53 & 20.25 & 19.98 & 20.00 & 19.73 & 20.50 & 20.23 & 20.25 & 19.98 \\
\hline TSS (mgTSS/l) & 29.00 & 26.46 & 32.25 & 31.89 & 32.00 & 33.38 & 33.75 & 35.75 & 34.00 & 37.68 \\
\hline Methane $\left(\ell \mathrm{CH}_{4} / \mathrm{d}\right)$ & 2.31 & 31.4 & 2.05 & 2.64 & 1.49 & 2.01 & 1.13 & 1.67 & 0.59 & 1.21 \\
\hline Gas Comp $\left(\% \mathrm{CO}_{2}\right)$ & ND & 40.1 & ND & 40.1 & $\mathrm{ND}$ & 40.1 & ND & 40.1 & ND & 40.1 \\
\hline COD Balance (\%) & 88.6 & 100.0 & 91.5 & 100.0 & 92.4 & 100.0 & 92.4 & 100.0 & 89.8 & 100.0 \\
\hline N Balance $(\%)$ & 102.3 & 100.0 & 99.6 & 100.0 & 100.3 & 100.0 & 101.2 & 100.0 & 98.2 & 100.0 \\
\hline
\end{tabular}

*Unbiodegradable fraction of the $\mathrm{AS}\left(\mathrm{f}_{\mathrm{AS} \text { up }}\right)$ based on $\mathrm{OHO}$ unbiodegradable fraction $\left(\mathrm{f}_{\mathrm{EH}}{ }^{\prime}\right)=0.08$ of death-regeneration model.

$\mathrm{ND}=$ Not determined

that measured. For AD0, AD1 and AD2 realistic $\mathrm{S}_{\mathrm{bp}}$ concentrations were obtained. However, for AD3 and AD4, -ve $\mathrm{S}_{\mathrm{bp}}$ values were obtained. This indicated that the measured effluent COD concentrations for AD3 and AD4 were lower than the sum of the unbiodegradable COD concentration (obtained from the measured active fraction) and anaerobic biomass COD concentrations generated, which implied that some COD considered unbiodegradable from the active fraction was digested in AD3 and AD4. To determine how much of this unbiodegradable COD was digested in AD3 and AD4, the $\mathrm{f}_{\text {AS'up }}$ of the feed WAS was decreased from the measured active fraction value so that a low positive $\mathrm{S}_{\mathrm{bp}}$ concentration $(\sim 0.05 \mathrm{~g} / \ell)$ was obtained in the calculations. The $\mathrm{f}_{\mathrm{AS} \text { 'up }}$ fractions so obtained for AD3 and AD4 were 0.727 and 0.786 . Comparisons of the resulting AD model predicted and experimentally measured effluent COD concentrations and methane productions are shown in Figs. $2 a$ and $b$ respectively. The effluent COD concentrations match exactly as expected from the method of calculation. The predicted methane production has the correct slope, but is higher than that measured. The reason for the over-prediction of the methane production is because the experimental systems have lower than $100 \%$ COD mass balances - these ranged between 90 to $95 \%$. If the AD effluent $S_{b p}$ is increased (effectively decreasing the WAS hydrolysis kinetic rate) so that the calculated methane production matches that measured very closely, then the total effluent COD concentration is over predicted by about $2 \mathrm{gCOD} / \ell$, which 


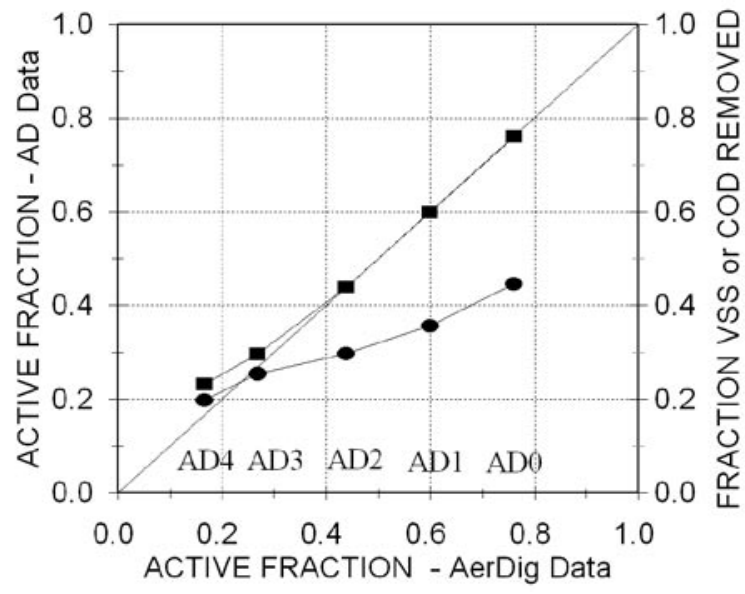

Figure 3

Active fraction of the feed WAS determined from the AD experimental data ( $\mathbf{\square}$ ) with the steady state $A D$ model of Sötemann et al. (2005a) and the measured fraction of VSS (or COD) removal (•) versus active fraction of the WAS determined from the aerobic digester experimental results.

is the approximate concentration of the missing COD (equivalent to about $0.8 \mathrm{l} / \mathrm{d}$ methane - Fig. $2 \mathrm{~b}$ ).

The experimentally measured and AD model theoretically calculated unbiodegradable COD fraction $\left(f_{A S, u p}\right)$ of the WAS feed is shown in Fig. 2c. It can be seen that the correspondence is very good for $\mathrm{AD} 0, \mathrm{AD} 1$ and $\mathrm{AD} 2$ (i.e. $0.300,0.449$ and 0.596 respectively). This means that for these ADs, the unbiodegradable COD fraction of the WAS feed matched that measured in the R0 to R2 aerobic systems. However, the unbiodegradable COD fraction of the WAS feed determined for anaerobic digesters AD3 and AD4 were 0.727 and 0.786 compared with 0.754 and 0.847 measured in the $\mathrm{R} 3$ and $\mathrm{R} 4$ aerobic digesters. This means that in AD3, $0.754-0.727=0.027$ or $2.7 \%$ and in AD4, $0.847-0.786=0.063$ or $6.3 \%$ more COD was biodegradable than available from the active fraction of the R3 and R4 WAS feed. These differences are less than the error on the COD balance. It can therefore be accepted, within the accuracy of experimental measurement, that the unbiodegradable components in activated sludge remain unbiodegradable under anaerobic digestion conditions.

In their evaluation of the biodegradability of WAS, Van Haandel et al. (1998b) plotted the fraction VSS removal (or equivalently, fraction COD removal through the $1.5 \mathrm{mgCOD} /$ mgVSS ratio for the influent and effluent solids) versus the active fraction of the WAS feed measured in the aerobic systems (Fig. 3). A straight line through the data cuts the vertical axis at 0.15 VSS removal. From this they inferred that at zero influent active fraction WAS feed, i.e. all unbiodegradable organics, 0.15 VSS removal would still take place, suggesting that $15 \%$ of the unbiodegradable activated sludge organics are biodegradable under anaerobic conditions. However, the above detailed evaluation of the data shows that the active fraction of the influent WAS calculated with the steady state AD model of Sötemann et al. (2005a), i.e. $\mathrm{f}_{\mathrm{av}}=\left(1-\mathrm{f}_{\mathrm{AS} \text { 'up }}\right) /\left(1-\mathrm{f}^{\prime}{ }_{\mathrm{EH}}\right)$, calibrated to fit the AD experimental data, matches very closely the active fraction of the WAS feed determined from the aerobic systems (Fig. 3). Interestingly, the specific hydrolysis rate constant $\left[\mathrm{K}_{\mathrm{H}}, \ell /(\mathrm{gCOD}\right.$ biomass.d)] for the WAS was only around $1 / 3$ rd of that for a primary and humus sludge mixture and $1 / 10$ th of that for pure primary sludge (Sötemann et al., 2005a; Ristow et al., 2005). With such a slow hydrolysis rate, a considerable (but decreasing with decreasing influent WAS active fraction) proportion of $\mathrm{OHO}$ biomass remains undi- gested at $20 \mathrm{~d}$ retention time. Therefore it cannot be assumed for WAS, as can be for primary sludge, that at $20 \mathrm{~d}$ retention time, most of the biodegradable organics are digested when the WAS active fraction is high. Gossett and Belser (1982) found the same - their six ADs at $15 \mathrm{~d}$ retention time did not utilise all the biodegradable organics in the WAS because the hydrolysis rate of WAS was too slow. The fact that not all the biodegradable organics of the WAS were utilised in the ADs of Van Haandel et al. (1998b) casts some uncertainty on the outcome that the unbiodegradable part of the WAS remains unbiodegradable under AD conditions. To confirm the conclusion, the authors did their own experimental investigation (see below).

\section{Estimating the CHON composition of WAS}

Having calibrated the kinetic part of the AD model to match the calculated effluent COD concentration with that measured for $\mathrm{AD} 0$ to AD4, the stoichiometric and carbonate weak acid base chemistry parts of the model were used to calculate the gas composition, effluent free and saline ammonia (FSA) and alkalinity (Alk) concentrations and the digester $\mathrm{pH}$. These parts of the AD model requires $\mathrm{X}, \mathrm{Y}, \mathrm{Z}$ and $\mathrm{A}$ in $\mathrm{C}_{\mathrm{X}} \mathrm{H}_{\mathrm{Y}} \mathrm{O}_{\mathrm{Z}} \mathrm{N}_{\mathrm{A}}$ of the biodegradable organics of WAS to be known. To determine these four unknowns at least five measurements are required, viz. the $\% \mathrm{C}$, $\% \mathrm{H}, \% \mathrm{O}$ and $\% \mathrm{~N}$ content of the VSS. The organics (VSS) and inorganics (ISS) cannot be separated before CHON elemental analysis so the TSS measurement also is required in that the $\% \mathrm{C}$, $\% \mathrm{H}, \% \mathrm{O}$ and $\% \mathrm{~N}$ of the TSS are measured. Elemental analysis for $\% \mathrm{O}$ is not usually done so this measurement is replaced by the COD and the $\% \mathrm{~N}$ can be replaced by the organic $\mathrm{N}(\mathrm{OrgN})$ obtained from the difference between the unfiltered and filtered TKN (see author data section below). From the COD, VSS, TKN and FSA measurements on the AD influent and effluent, the $\mathrm{X}$ and $\mathrm{A}$ could be determined requiring $\mathrm{Y}$ and $\mathrm{Z}$ to be set at assumed values due to the absence of elemental analysis. The $\mathrm{X}$ and A were calculated from the VSS and COD removals and the FSA released in the digesters. The average COD/VSS $(f)$ and N/VSS $\left(f_{n}\right)$ ratios of the biodegradable particulate organics of WAS calculated in this way for AD0 to AD4 were $1.55 \mathrm{mgCOD} /$ $\mathrm{mgVSS}$ and $66.0 \mathrm{mgN} / \mathrm{gCOD}$. These ratios are very close to the ratios measured directly on the influent particulate WAS, i.e. 1.50 $\mathrm{mgCOD} / \mathrm{mgVSS}$ and $65.8 \mathrm{mgN} / \mathrm{gCOD}$ which are the ratios of the mixture of the biodegradable and unbiodegradable WAS organics. From the influent (mixture) and the biodegradable organics ratios, and knowing the unbiodegradable fraction of the WAS $\left(\mathrm{f}_{\mathrm{AS}, \text { up }}\right)$ from the kinetic part of the model, the N/COD ratio of the unbiodegradable WAS organics can be calculated from a mass balance. The average N/COD ratio of the unbiodegradable particulate organics of WAS for AD0 to AD4 is $68.5 \mathrm{mgN} / \mathrm{gCOD}$. This is very close to the biodegradable organics N/COD ratio, which is expected for WAS from the activated sludge system behaviour. Unless all the biodegradable organics of WAS are utilised in the digester, the COD/VSS ratio of the unbiodegradable particulate organics of WAS cannot be determined directly because the unbiodegradable fraction of the VSS is not known.

If the COD/VSS $\left(f_{c v}\right), C / V S S ~\left(f_{c}\right)$ and N/VSS $\left(f_{n}\right)$ ratios of the biodegradable organics are known, $\mathrm{X}, \mathrm{Y}, \mathrm{Z}$ and $\mathrm{A}$ can be calculated from Eqs. (1) to (4), i.e.

$$
\begin{aligned}
& Y=7 \\
& Z=\frac{Y\left(1-f_{c v} / 8-8 f_{c} / 12-17 f_{n} / 14\right)}{2\left(1+f_{c v}-44 f_{c} / 12+10 f_{n} / 14\right)} \\
& X=\frac{f_{c}(Y+16 Z)}{12\left(1-f_{c}-f_{n}\right)}
\end{aligned}
$$



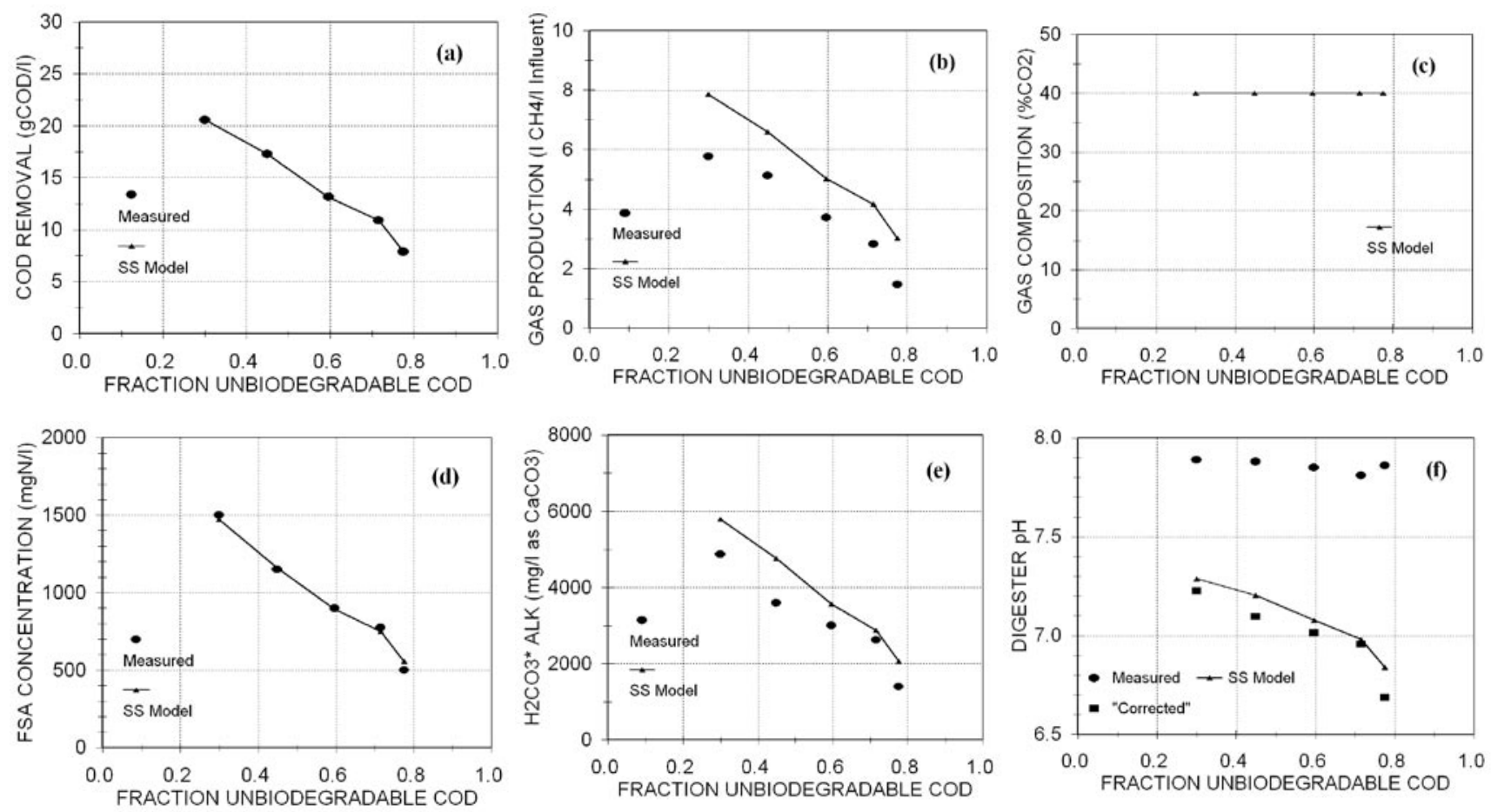

Figure 4

Comparison between steady state (SS) anaerobic digestion model predicted (lines) and Van Haandel et al.

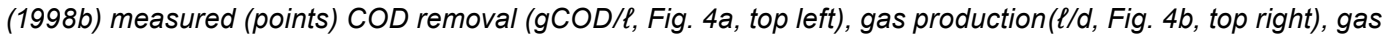
composition ( $\mathrm{pCO} 2$, Fig. $4 \mathrm{c}$, middle left), effluent FSA (mgN/l, Fig. $4 d$, middle right), $\mathrm{H} 2 \mathrm{CO}^{*}{ }^{*}$ Alkalinity (mg/l as $\mathrm{CaCO}$, Fig. 4e, bottom left) and digester $\mathrm{pH}$ (Fig. 4f, bottom right) vs. unbiodegradable particulate COD fraction of the feed waste activated sludge.

$$
A=\frac{f_{n}(Y+16 Z)}{14\left(1-f_{c}-f_{n}\right)}
$$

Accepting $\mathrm{Y}=7$ and $\mathrm{Z}=2$ in $\mathrm{C}_{\mathrm{X}} \mathrm{H}_{\mathrm{Y}} \mathrm{O}_{\mathrm{Z}} \mathrm{N}_{\mathrm{A}}$ from Sötemann et al. (2005a) and the average $f_{c v}$ and $f_{n}$ ratios calculated for the biodegradable organics of WAS, i.e. $f_{c v}=1.55 \mathrm{mgCOD} / \mathrm{mgVSS}$ and $\mathrm{f}_{\mathrm{n}}=0.102 \mathrm{mgN} / \mathrm{mgVSS}\left(\mathrm{f}_{\mathrm{ZB}^{\prime} \mathrm{N}}=66 \mathrm{mgN} / \mathrm{gCOD}\right)$, Eqs. (1) to (4) yield $\mathrm{f}_{\mathrm{c}}=0.570 \mathrm{mgC} / \mathrm{mgVSS}, \mathrm{X}=5.67$ and $\mathrm{A}=0.865$, i.e. $\mathrm{C}_{5.67} \mathrm{H}_{7} \mathrm{O}_{2} \mathrm{~N}_{0.865}$. This is not too far from the $\mathrm{C}_{4.80} \mathrm{H}_{7} \mathrm{O}_{2} \mathrm{~N}_{0.77}$ obtained from the commonly accepted ratios for AS, i.e. $\mathrm{f}=$ $1.48 \mathrm{mgCOD} / \mathrm{mgVSS}$ and $\mathrm{f}_{\mathrm{n}}=0.10 \mathrm{mgN} / \mathrm{mgVSS}\left(\mathrm{f}_{\mathrm{ZB}, \mathrm{N}}=67.6\right.$ $\mathrm{mgN} / \mathrm{gCOD}$ ). The measured $\mathrm{C}_{5.67} \mathrm{H}_{7} \mathrm{O}_{2} \mathrm{~N}_{0.865}$ stoichiometric formula for biodegradable organics of WAS was set as input to the stoichiometric and carbonate chemistry parts of the AD model.

The model calculated and experimentally measured results for AD0 to AD4 are shown in Figs. 4a to f. As in Figs. 2a and b, the COD removal (Fig. 4a) is closely predicted but the methane production over-predicted (Fig. 4b). The effluent FSA (Fig. 4d) is closely predicted indicating that the $\mathrm{N}$ content of the WAS biodegradable organics at $\mathrm{f}_{\mathrm{ZB.N}}=66.0 \mathrm{mgN} / \mathrm{gCOD}$ accepted for the biodegradable particulate organics was accurately estimated. Van Haandel et al. (1998b) did not measure the full gas flow, only the methane production. The gas composition, or partial pressure of $\mathrm{CO}_{2}\left(\mathrm{p}_{\mathrm{CO} 2}\right)$, therefore is not known. The carbon content of the WAS therefore could not be confirmed from a carbon balance and the formula for the biodegradable particulate organics could not be refined. From $\mathrm{C}_{5.67} \mathrm{H}_{7} \mathrm{O}_{2} \mathrm{~N}_{0.865}$, the theoretical $\mathrm{p}_{\mathrm{CO} 2}=40.1 \%$ (Fig. $4 \mathrm{c}$ ).

The theoretically calculated alkalinity (Alk) is over-predicted (Fig. 4e). Van Haandel et al. (1998b) measured an $\mathrm{H}_{2} \mathrm{CO}_{3}$ * Alkalinity generation of $0.274 \mathrm{mgAlk}$ as $\mathrm{CaCO}_{3}$ per mgVSS removed. Stoichiometrically from $\mathrm{C}_{5.67} \mathrm{H}_{7} \mathrm{O}_{2} \mathrm{~N}_{0.865}$, the Alkalinity generation is $0.363 \mathrm{mgAlk}$ as $\mathrm{CaCO}_{3}$ per $\mathrm{mgVSS}$ removed. With a WAS feed in which there is presumably a very low influent VFA concentration (Van Haandel et al., 1998b do not give influent VFA data), in the AD model the effluent Alk and FSA concentrations are directly linked with $1 \mathrm{~mol} \mathrm{HCO}_{3}^{-}$for each mol FSA generated at pH 7.0 (Eq. (27) in Sötemann et al., 2005a). Hence, the predicted Alk can be reduced by reducing the $\mathrm{N}$ content of the WAS, but this would result in under-prediction of the effluent FSA concentration. It is not clear why in the experimental data, the alkalinity generation is low relative to the ammonia released. A possible explanation is that some of the ammonia groups in the WAS do not generate alkalinity when hydrolysed and released as FSA, possibly due to being present in the side chains of amino-acids (e.g. lysine); this requires further investigation. The digester $\mathrm{pH}$ was measured at around 7.8. This is much higher than that theoretically calculated, which is between 7.3 and 6.8 (Fig. 4f). For the measured Alk and calculated $\mathrm{p}_{\mathrm{CO} 2}$ of 0.401 , such a high measured $\mathrm{pH}$ does not conform to the carbonate weak acid base chemistry part of the model. If $\mathrm{p}_{\mathrm{CO} 2}=$ 0.401 is correct, then for the measured Alk, the "corrected" $\mathrm{pH}$ should be between 7.2 and 6.7, slightly below the theoretically calculated $\mathrm{pH}$. Furthermore, increasing $\mathrm{p}_{\mathrm{CO} 2}$ (i.e. super-saturation) causes the $\mathrm{pH}$ to decrease so that disequilibrium through super-saturation cannot explain the high measured $\mathrm{pHs}$. Possibly $\mathrm{CO}_{2}$ loss on sampling and testing caused an increase in measured $\mathrm{pH}$.

\section{Sensitivity of partial pressure of $\mathrm{CO}_{2}\left(p_{\mathrm{CO} 2}\right)$ to sludge composition}

Because the $\mathrm{p}_{\mathrm{CO} 2}$ is not known for the Van Haandel et al. (1998b) data, the sensitivity of $\mathrm{p}_{\mathrm{CO} 2}$ to the $\mathrm{C}$ and $\mathrm{N}$ content of WAS was explored theoretically and is shown in Fig. 5. It can be seen 


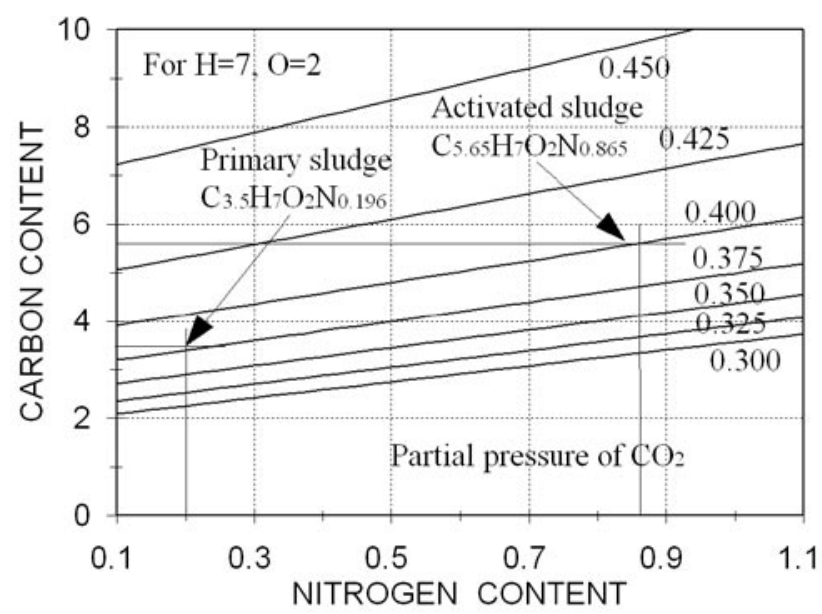

Figure 5

Partial pressure of carbon dioxide in the digester gas ( $p C O 2)$ $v s$. the nitrogen $(A)$ and carbon $(X)$ content of the feed sludge composition as CXH7O2NA calculated from the stoichiometry of the AD model of Sötemann et al. (2005a).

that the $\mathrm{p}_{\mathrm{CO} 2}$ is not very sensitive to even significant changes in $\mathrm{C}$ and $\mathrm{N}$ content. For example, Sötemann et al. (2005a) determined by elemental analysis of PS and COD, C and N mass balances around the primary and humus sludge fed digesters of Izzett et al. (1992), the CHON content of this influent sludge to be $\mathrm{C}_{3.5} \mathrm{H}_{7} \mathrm{O}_{2} \mathrm{~N}_{0.196}$, which yields a $\mathrm{p}_{\mathrm{CO} 2}=0.375$. For the WAS CHON content of $\mathrm{C}_{5.67} \mathrm{H}_{7} \mathrm{O}_{2} \mathrm{~N}_{0.865}$, the $\mathrm{p}_{\mathrm{CO} 2}$ is 0.401 , a relatively small difference for a large difference in $\mathrm{C}$ and $\mathrm{N}$ content. So while improved prediction between measured and calculated results can be obtained by adjusting the $\mathrm{C}$ and $\mathrm{N}$ content of the WAS, such accuracy is unwarranted in the absence of $\mathrm{p}_{\mathrm{CO} 2}$ measurements. The principal objective of this investigation was not AD model validation, but to establish whether or not the unbiodegradable organics in WAS under aerobic conditions remain unbiodegradable under anaerobic conditions. Within experimental error, this seems to be the case, but this needs to be confirmed by running WAS fed ADs at a very long retention time to ensure that the WAS biodegradable organics are completely digested (see author data below).

\section{Conservation of influent (fixed) ISS in anaerobic digestion of WAS}

Taking due consideration of the OHO contribution to the ISS of the influent WAS feed to AD0 to AD4, and the decrease in ISS that takes place as a result of $\mathrm{OHO}$ digestion, 126, 100, 88, 85 and $78 \%$ of the fixed ISS (originally present in the influent raw wastewater) was recovered in the effluent of AD0 to AD4 respectively - average $96 \%$. The fixed ISS recovery varies considerably between $\mathrm{AD} 0$ and AD4 and decreases progressively as lower concentrations of OHO ISS were fed. It is unclear if this progressive decrease is caused by precipitation in the $\mathrm{AD}$ when fed high OHO ISS concentrations (AD0) and dissolution of fixed ISS when fed low OHO ISS concentration (AD2 to AD4). Even though the average recovery is $96 \%$, more data are required to establish whether or not influent wastewater inorganic particulate material is conserved through ADs at WWTPs. At fullscale WWTP mixing energies in sludge treatment digesters are not as high as in small laboratory or pilot scale systems, with the result that settlement of inorganic material from the influent in the digesters often occurs. This will result in a low fixed inorganic material recovery in and a higher VSS/TSS ratio of the final sludge.

\section{Confirming the biodegradability of WAS - author data}

In order to check the conclusion above that the unbiodegradable organics in WAS remain unbiodegradable under anaerobic digester, a $15 \mathrm{~d}$ sludge age $\mathrm{N}$ removal activated sludge (AS) system was set up, the WAS of which was fed to a $60 \mathrm{~d}$ retention time anaerobic digestion (AD) over a period of about $150 \mathrm{~d}$. The AS system was fed $15 \mathrm{l} / \mathrm{d}$ raw wastewater, the COD concentration of which averaged $807 \mathrm{mg} / \ell$. The AS reactor had a volume of $15 \mathrm{l}$ and was aerated intermittently ( $3 \mathrm{~h}$ on, $3 \mathrm{~h}$ off) for nitrification denitrification (ND). The unbiodegradable soluble and particulate COD fractions $\left(\mathrm{f}_{\text {S'us }}\right.$ and $\mathrm{f}_{\text {S'up }}$ ) and the VSS/TSS ratio $\left(f_{i}\right)$ were determined to be $0.050,0.10$ and 0.86 respectively. From the $\mathrm{f}_{\text {S'us }}$ and $\mathrm{f}_{\text {S }^{\prime} \text { up }}$ values, the active fraction of the WAS with respect to the VSS $\left(f_{a y}\right)$ was calculated to be 0.395 (Marias and Ekama, 1976; WRC, 1984). Hence, the unbiodegradable COD

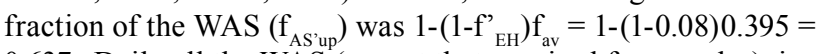
0.637 . Daily all the WAS (except that required for samples), i.e. $1 \mathrm{l} / \mathrm{d}$ at $\sim 2.5 \mathrm{gVSS} / \mathrm{l}$, was thickened 3 times to $0.33 \mathrm{l} / \mathrm{d}$ and fed to a $20 l$ anaerobic digester. The digester was operated for about two retention times (4 months) to reach steady state and thereafter was tested daily for $15 \mathrm{~d}$. Additionally, daily equal masses of dried influent and effluent solids were composited and tested for $\mathrm{C}, \mathrm{H}$ and $\mathrm{N}$ composition by elemental analysis. The average experimentally measured results are listed in Table 2.

The measured influent COD concentration (10 $714 \mathrm{mg} / \mathrm{l})$, unbiodegradable COD fraction $\left(\mathrm{f}_{\mathrm{AS} \text { 'up }}=0.637\right)$ and effluent COD concentration were set as input to the hydrolysis kinetic part of the steady state AD model of Sötemann et al. (2005a, their Eq. 25). The residual biodegradable COD concentration $\left(\mathrm{S}_{\mathrm{bp}}\right)$ was calculated to be very low $(0.031 \mathrm{~g} / \mathrm{l})$. Such a low $\mathrm{S}_{\mathrm{bp}}$ is expected for the $60 \mathrm{~d}$ retention time. If $\mathrm{S}_{\mathrm{bp}}$ is assumed zero, the calculated $\mathrm{f}_{\mathrm{AS} \text { 'up }}$ is 0.627 . This is remarkably close to the $\mathrm{f}_{\mathrm{AS} \text { 'up }}=$ 0.637 calculated from the AS model and confirms that the unbiodegradable organics from the AS system remain unbiodegradable in the AD systems. The theoretically calculated effluent COD concentration, COD removal and methane production are compared with the experimentally measured values in Table 2 . The effluent COD concentration and COD removal are almost equal, but the methane production is somewhat under-predicted. This is because the experimental system COD balance is $104 \%$, whereas the AD model is based on a $100 \%$ COD balance.

\section{Estimating the CHON composition of WAS - author data}

The $\mathrm{X}, \mathrm{Y}, \mathrm{Z}$ and $\mathrm{A}$ values in $\mathrm{C}_{\mathrm{X}} \mathrm{H}_{\mathrm{Y}} \mathrm{O}_{\mathrm{Z}} \mathrm{N}_{\mathrm{A}}$ of the influent solids were calculated as follows: Of the measured TSS concentration $(7867 \mathrm{mg} / \ell)$, from elemental analysis $44.5 \%$. $7.04 \%$ and $6.02 \%$ are the concentrations of $\mathrm{C}, \mathrm{H}$ and $\mathrm{N}$, i.e. $3492 \mathrm{mgC} / \mathrm{l}$, $552 \mathrm{mgH} / \ell$ and $472 \mathrm{mgN} / \ell$. The balance of the TSS is O and ISS, or equivalently, the balance of the measured VSS (6 $755 \mathrm{mg} / \ell)$ is $\mathrm{O}$, i.e. $2163 \mathrm{mgO} / \ell$. These four constituent concentrations give a composition relative to $\mathrm{Y}=7$ of $\mathrm{C}_{3.513} \mathrm{H}_{7.0} \mathrm{O}_{1.726} \mathrm{~N}_{0.431}$. The $\mathrm{COD} / \mathrm{VSS}$ ratio of this generic WAS organic is $1.604 \mathrm{mgCOD} /$ mgVSS, which for the measured VSS concentration of 6755 $\mathrm{mg} / \ell$ gives a COD concentration of $10837 \mathrm{mgCOD} / \ell$. This is $6 \%$ higher than the measured particulate COD concentration (10 $217 \mathrm{mg} / \ell$ ), indicating that there is an $6 \%$ error in the measurements. This error was accepted to be on the $\mathrm{O}$ content so the $\mathrm{Z}$ value was increased such that the measured and calculated COD 


\begin{tabular}{|c|c|c|c|c|}
\hline \multicolumn{5}{|c|}{$\begin{array}{c}\text { TABLE } 2 \\
\text { Average experimentally measured and theoretically calculated results } \\
\text { for the } 60 \mathrm{~d} \text { retention time anaerobic digester at } 37^{\circ} \mathrm{C} \text { fed waste activate } \\
\text { sludge from a } 15 \mathrm{~d} \text { sludge age ND activated sludge system }\end{array}$} \\
\hline \multirow[t]{2}{*}{ Parameter } & \multirow[t]{2}{*}{ Influent } & \multicolumn{3}{|c|}{ Effluent } \\
\hline & & Experimental & Theoretical $^{1}$ & Theoretical $^{2}$ \\
\hline Total COD (mg/l) & 10714 & 6993 & 6984 & 6984 \\
\hline Soluble COD $(\mathrm{mg} / \ell)$ & 497 & 173 & 0 & 0 \\
\hline VFA (mg/l as acetic acid) & 254 & 8 & 0 & 0 \\
\hline Gas flow $(\ell / d)$ & - & 0.859 & 0.726 & 0.749 \\
\hline Methane flow (l/d) & - & 0.521 & 0.476 & 0.476 \\
\hline Gas composition $\left(\% \mathrm{CO}_{2}\right)$ & - & 39.4 & 34.4 & 36.7 \\
\hline Methane prod. (mgCOD/l) & - & 4096 & 3730 & 3730 \\
\hline COD removal $(\mathrm{mg} / \mathrm{l}, \%)$ & & $3721,34.7$ & $3730,34.8$ & $3730,34.8$ \\
\hline Total COD out (mgCOD/l) & - & 11089 & 10714 & 10714 \\
\hline COD balance & & $103.5 \%$ & $100.0 \%$ & $100 \%$ \\
\hline TKN (mgN/l) & 809 & 706 & 809 & 809 \\
\hline FSA $(\mathrm{mgN} / \mathrm{l})$ & 43.1 & 276 & 227 & 276 \\
\hline Organic N (mgN/l) & 766 & 430 & 582 & 533 \\
\hline Nitrogen balance & - & 87 & 100 & 100 \\
\hline Carbon balance & - & 106.9 & 100 & 100 \\
\hline $\mathrm{VSS}(\mathrm{mg} / \mathrm{l})$ & 6755 & 4400 & $4395^{3}$ & $4241^{3}$ \\
\hline $\mathrm{N} / \mathrm{COD}$ ratio (mgN/gCOD) & 75.0 & $63.1^{5} / 68.6^{6}$ & $83.3^{5} / 49.3^{6}$ & $76.3^{5} / 62.5^{6}$ \\
\hline Digester $\mathrm{pH}$ & 6.82 & $7.19 / 6.61^{7}$ & 6.62 & 6.66 \\
\hline Alkalinity $\left(\mathrm{mg} / \ell\right.$ as $\left.\mathrm{CaCO}_{3}\right)$ & 227 & 1207 & 1080 & 1256 \\
\hline $\mathrm{TSS}(\mathrm{mg} / \mathrm{l})$ & 7847 & 5355 & 5105 & 4951 \\
\hline ISS (mg/l) & 1092 & 955 & 710 & 710 \\
\hline Fixed ISS (mg/l) & 694 & $(694)$ & $(694)$ & $(694)$ \\
\hline OHO ISS (mg/l) & 398 & 261 & 16 & 16 \\
\hline VSS/TSS ratio & 0.861 & 0.822 & 0.861 & 0.857 \\
\hline COD/VSS ratio of solids & $1.513^{4}$ & $1.55^{5} / 1.44^{6}$ & $1.59^{5} / 1.58^{6}$ & $1.65^{5} / 1.48^{6}$ \\
\hline \multicolumn{5}{|c|}{$\begin{array}{l}{ }^{1} \text { Based on } \mathrm{C}_{3.691} \mathrm{H}_{7} \mathrm{O}_{1.990} \mathrm{~N}_{0.503} \text { determined for the biodegradable WAS organics removed (see text). } \\
{ }^{2} \text { Based on } \mathrm{C}_{4.80} \mathrm{H}_{7} \mathrm{O}_{2} \mathrm{~N}_{0.77} \text { with COD/VSS and TKN/VSS ratios of } 1.48 \text { and } 0.10 \text { commonly } \\
\text { accepted for AS. } \\
{ }^{3} \text { Calculated from COD removed divided by COD/VSS ratio of organics removed. } \\
{ }^{4} \text { Measured on the influent particulate organics, i.e. mixed bio- and unbiodegradable. } \\
{ }^{5} \text { of the remaining undigested organics, which is mostly unbiodegradable (except of the } \\
\text { anaerobic biomass, which is small) due to the very long retention time. } \\
6 \text { of the removed (digested) organics (biodegradable) - calculated from the VSS and particulate } \\
\text { COD removed and FSA released. } \\
77^{7} \text { "Corrected" experimentally measured pH calculated from the measured } \mathrm{p}_{\mathrm{CO} 2} \text { and } \mathrm{H}_{2} \mathrm{CO}_{3}{ }^{*} \\
\text { Alkalinity. }\end{array}$} \\
\hline
\end{tabular}

the stoichiometric and weak acid base chemistry parts of the AD model. The results are listed in Table 2. To give an indication of the sensitivity of the predicted results to the composition of the biodegradable organics removed, the composition of AS commonly accepted in AS models also was set as input to the AD model, i.e. $\mathrm{C}_{4.80} \mathrm{H}_{7.0} \mathrm{O}_{2.0} \mathrm{~N}_{0.77}$ with COD/VSS and TKN/VSS ratios of 1.48 and 0.10 respectively. The results are also listed in Table 2. This approach is the same as is done in ADM1 (Batstone et al., 2002) in which the measured influent $\mathrm{COD}, \mathrm{C}, \mathrm{H}, \mathrm{O}$ and $\mathrm{N}$ concentrations are transformed to concentrations of influent carbohydrates, lipids and proteins based on $\mathrm{COD}, \mathrm{C}, \mathrm{H}, \mathrm{O}$ and $\mathrm{N}$ mass balances. The only difference in the steady state model is that $\mathrm{C}_{\mathrm{X}} \mathrm{H}_{\mathrm{Y}} \mathrm{O}_{\mathrm{Z}} \mathrm{N}_{\mathrm{A}}$ is the generic organic compound representing the mixture of influent carbohydrate, lipids and proteins with the measured COD, $\mathrm{C}, \mathrm{H}, \mathrm{O}$ and $\mathrm{N}$ concentrations. The steady state model does not consider the organic intermediates because these are assumed to be completely utilised.

For the measured sludge composition, the theoretically predicted and experimentally measured results correlate reasonably well. The methane gas production is underpredicted and the gas composition $\left(\% \mathrm{CO}_{2}\right.$ or $\left.\mathrm{p}_{\mathrm{CO} 2}\right)$ over-predicted. Because the effluent COD concentration is closely predicted, the error of experimental COD balance manifests in the methane production - the $0.045 \mathrm{l} / \mathrm{d}$ higher methane production observed experimentally almost exactly matches the $3.5 \%$ of the $103.5 \%$ COD balance. The theoretical effluent ammonia (FSA) and

concentrations matched, i.e. $Z=1.921$ yielding $\mathrm{C}_{3.513} \mathrm{H}_{7.0} \mathrm{O}_{1.921} \mathrm{~N}_{0.431}$. For the effluent particulate material, this procedure yielded $\mathrm{C}_{3.724} \mathrm{H}_{7.0} \mathrm{O}_{1.885} \mathrm{~N}_{0.393}$. The difference between the influent and effluent $\mathrm{C}, \mathrm{H}, \mathrm{O}$ and $\mathrm{N}$ masses yielded $\mathrm{C}_{3.691} \mathrm{H}_{7.0} \mathrm{O}_{1.990} \mathrm{~N}_{0.503}$, which is the measured composition of the biodegradable particulate organics removed, accepting the very small error introduced by not taking the anaerobic biomass generation into account. The results of these calculations are listed in Table 3. From these results the COD, $\mathrm{N}$ and $\mathrm{C}$ mass balances over the $\mathrm{AD}$ were 104 , 109 and $107 \%$ respectively. While these balances are within an acceptable range, the $\mathrm{N}$ balances calculated from the TKN and FSA results and the elemental analysis and FSA results are significantly different ( $87 \%$ and $109 \%)$ and will cause some deviation between predicted and experimental results.

Accepting that the WAS biodegradable organics were completely utilised, the COD concentration removed and its elemental composition $\mathrm{C}_{3.691} \mathrm{H}_{7.0} \mathrm{O}_{1.990} \mathrm{~N}_{0.503}$ were set as input to alkalinity concentrations are under predicted by $49 \mathrm{mgN} / \ell$ and $127 \mathrm{mg} / \ell$ as $\mathrm{CaCO}_{3}$ respectively, which indicates that more ammonia was measured experimentally to be released from the digested organics than predicted theoretically. This arises from an error in the elemental analysis of the solids. If the $\mathrm{N}$ content of the biodegradable WAS is increased to $\mathrm{N}_{0.580}$ (from $\mathrm{N}_{0.503}$ ) then the effluent FSA and alkalinity concentrations are almost exactly predicted ( $264 \mathrm{mgN} / \ell$ and $1214 \mathrm{mg} / \ell$ as $\mathrm{CaCO}_{3}$ ). The measured TKN and FSA results were not used to calculate the influent and effluent sludge $\mathrm{N}$ composition because based on these measurements the $\mathrm{N}$ balance was only $87 \%$ whereas the $\mathrm{N}$ balance based on the elemental analysis and FSA results is $109 \%$. The digester $\mathrm{pH}$ is under predicted (6.61 vs. 7.19). The measured $\mathrm{pH}$ of 7.19 does not conform to the measured alkalinity and $\mathrm{CO}_{2}$ partial pressure results. The $\mathrm{pH}$ corresponding to these two measured values is 6.62 , which is very close to the predicted value. 
TABLE 3

Calculation of $\mathrm{CHON}$ composition of biodegradable WAS organics from wet chemical (COD, VSS, TSS) and elemental analysis of AD influent and effluent dried solids. The calculation progresses downwards in the influent and effluent columns, across via subtraction of effluent from influent $\mathrm{C}, \mathrm{H}, \mathrm{O}$ and $\mathrm{N}$ masses to obtain the $\mathrm{C}, \mathrm{H}, \mathrm{O}$ and $\mathrm{N}$ removals, and then upwards in the removal column to determine $X$, $\mathrm{Y}, \mathrm{Z}$ and $\mathrm{N}$ of the removed organics.

\begin{tabular}{|c|c|c|c|c|}
\hline \multicolumn{2}{|l|}{ Parameter } & Influent & Effluent & Removed \\
\hline TSS & $\mathrm{mgTSS} / \ell$ & 7847 & 5355 & 2492 \\
\hline Carbon & \%TSS & 44.50 & 41.91 & - \\
\hline Hydrogen & $\% \mathrm{TSS}$ & 7.04 & 6.61 & - \\
\hline Nitrogen & \%TSS & 6.02 & 5.16 & - \\
\hline $\mathrm{X}$ & $\mathrm{C}$ & 3.713 & 3.724 & 3.691 \\
\hline $\mathrm{Y}$ & $\mathrm{H}$ & 7.000 & 7.000 & 7.000 \\
\hline Z & $\mathrm{O}$ & 1.921 & 1.885 & 1.990 \\
\hline $\mathrm{A}$ & $\mathrm{N}$ & 0.431 & 0.393 & 0.503 \\
\hline Mol mass & $\mathrm{gCOD} / \mathrm{mol}$ & 133.74 & 135.58 & 130.19 \\
\hline Conc & $\mathrm{mol} / \mathrm{l}$ & 76.40 & 50.31 & 26.086 \\
\hline Flow & $\ell / d$ & 0.333 & 0.333 & 0.333 \\
\hline Th COD & $\mathrm{mgCOD} / \mathrm{\ell}$ & 10218 & 6821 & 3396 \\
\hline Meas COD & $\mathrm{mgCOD} / \mathrm{l}$ & 10217 & 6821 & 3396 \\
\hline Th VSS & $\mathrm{mgVSS} / 1$ & 6748 & 4395 & 2352 \\
\hline Meas VSS & $\mathrm{mgVSS} / \mathrm{\ell}$ & 6755 & 4400 & 2355 \\
\hline$T h f_{c y}$ & COD/VSS & 1.5143 & 1.5520 & 1.4437 \\
\hline Meas $f_{c y}$ & COD/VSS & 1.5125 & 1.5502 & - \\
\hline TOC & $\mathrm{gC} / \mathrm{l}$ & 3404.0 & 2248.6 & 1155.41 \\
\hline Hydrogen & $\mathrm{gH} / \mathrm{\ell}$ & 534.8 & 352.2 & 182.60 \\
\hline Oxygen & $\mathrm{gO} / \mathrm{l}$ & 2348.1 & 1517.4 & 830.73 \\
\hline OrgN & $\mathrm{gN} / \mathrm{l}$ & 460.7 & 277.0 & 183.72 \\
\hline TOC/VSS & $\mathrm{f}_{c}$ & 0.5045 & 0.5116 & 0.4911 \\
\hline OrgN/VSS & $f_{n}$ & 0.0683 & 0.0630 & 0.0781 \\
\hline gN/gCOD & $\mathrm{f}_{\mathrm{Z}^{\prime} \mathrm{BH}}$ & 45.1 & 40.6 & 54.1 \\
\hline
\end{tabular}

For the commonly accepted WAS composition, the predicted results correlate better with the experimental results. The predicted methane gas production is unchanged. The gas composition is still under-predicted but closer to that measured. The predicted FSA and alkalinity concentrations $(276 \mathrm{mgN} / \ell$ and $1256 \mathrm{mg} / \ell$ as $\mathrm{CaCO}_{3}$ ) now correlate closely to the measured values $\left(276 \mathrm{mgN} / \mathrm{l}\right.$ and $1207 \mathrm{mg} / \mathrm{l}$ as $\left.\mathrm{CaCO}_{3}\right)$. The digester $\mathrm{pH}$ remains under predicted (6.62 vs. 7.19). While these deviations between predicted and measured results may point to some errors in experimental results, they do not change the conclusion from the investigation, viz. that the unbiodegradable organics in WAS, as defined by the "aerobic" conditions of the AS system, remain unbiodegradable under anaerobic conditions. From an investigation into the kinetics of aerobic and anaerobic digestion of WAS, Yasui et al. (2006) reach the same conclusion.

\section{Conservation of influent (fixed) ISS in anaerobic digestion of WAS}

With regard to the ISS, from the AS model, of the $1092 \mathrm{mg} / \mathrm{l}$ fed to the digester (Table 2), $692 \mathrm{mg} / \ell$ originated from the influent wastewater while $400 \mathrm{mg} / \mathrm{l}$ was contributed by the $\mathrm{OHO}$ biomass, viz. $\mathrm{f}_{\text {іоно }} \mathrm{f}_{\text {ау }} \mathrm{X}_{\mathrm{v}}=0.15 \mathrm{x} 0.395 \times 6755=400 \mathrm{mgISS} / \mathrm{l}$. The OHO biomass was completely digested and therefore the expected decrease in ISS concentration is $\sim 400 \mathrm{mg} / \mathrm{l}$. However, a decrease of only $139 \mathrm{mg} / \ell$ was measured. Because the anaerobic biomass concentration is so low, even if an ISS/VSS content of 0.15 were ascribed to it, it would make very little difference to the calculated ISS concentration ( $16 \mathrm{mgISS} / \mathrm{\ell}$, Table 2$)$. Hence experimentally, significantly more ISS (138\%) exited the WWTP system in the AD effluent than entered it with the influent raw wastewater. It is possible that mineral precipitation took place, but the tests to check this were not done on the AD.

\section{Conclusions}

From this investigation of the continuity of wastewater organic, inorganic and $\mathrm{N}$ compounds along the link connecting the fully aerobic or $\mathrm{N}$ removal activated sludge (AS) and anaerobic digestion (AD) unit operations, the following conclusions can be made:

- Applying the COD, carbon (C) and nitrogen (N) mass balances steady state AD model of Sötemann et al. (2005a) to literature data of waste activated sludge (WAS) AD showed that this model satisfactorily predicted AD performance (gas production and composition, effluent COD, free and saline ammonia and alkalinity concentrations) and provided a mass balance-based structure to determine the unbiodegradable particulate organic (COD) fraction of WAS $\left(\mathrm{f}_{\mathrm{AS} \text { 'up }}\right)$. For the Van Haandel et al. $(1998 \mathrm{a}, \mathrm{b})$ data, the $\mathrm{f}_{\mathrm{AS} \text { up }}$ determined from the AD model matched very closely that calculated for the WAS feed from the steady state AS model of Marais and Ekama (1976) or WRC (1984), provided the unbiodegradable fraction of the OHOs is assigned the value from the death-regeneration model (i.e. $\mathrm{f}_{\mathrm{EH}}=0.08$ ), not the value from the net effect endogenous respiration model $\left(\mathrm{f}_{\mathrm{EH}}=0.20\right)$. This was confirmed with the authors' own experimental data, which included $\mathrm{CHON}$ composition measurement of $\mathrm{AD}$ influent and effluent by elemental analysis.

- It follows from above that the influent wastewater unbiodegradable particulate organics determined from the response of the AS system and the unbiodegradable organics that are generated in the AS system itself, i.e. endogenous residue, are both unbiodegradable under AD conditions. The residual biodegradable organics of WAS that can be anaerobically digested therefore can be calculated from the active fraction of the WAS using the widely accepted AS stoichiometric $\left(\mathrm{f}_{\mathrm{EH}}=0.20 / \mathrm{f}_{\mathrm{EH}}=0.08, \mathrm{f}_{\mathrm{cv}} \approx 1.48 \mathrm{mgCOD} / \mathrm{mgVSS}, \mathrm{Y}_{\mathrm{H}}=\right.$ $0.45 \mathrm{mgVSS} / \mathrm{mgCOD})$ and kinetic constants $\left(\mathrm{b}_{\mathrm{H} 20}=0.24 / \mathrm{d}\right.$; $\mathrm{b}_{\mathrm{H} 20}=0.62 / \mathrm{d}$ ) included in steady state and dynamic simulation AS models. Earlier, Gossett and Belser (1982) came to the same conclusion but the $\mathrm{b}_{\mathrm{H} 20}$ and $\mathrm{f}_{\mathrm{EH}}$ values on which this was based (0.10/d and 0.317) are not compatible with those widely accepted in steady state and dynamic simulation AS models, possibly because they did not use real municipal wastewater.

- From the Van Haandel et al. (1998a,b) and author experimental results, between $138 \%$ and $78 \%$ of the influent (fixed) ISS concentration was recovered in the AD effluent. Ekama et al. (2006, Part 2) showed that influent ISS was conserved through aerobic digestion of WAS, but with such wide variation, the same cannot be concluded for AD of WAS.

- The COD/VSS and N/COD ratios obtained for the WAS biodegradable and unbiodegradable (endogenous) organics appear to be similar in magnitude and close to the commonly accepted ratios for activated sludge $(\mathrm{COD} / \mathrm{VSS}=$ 
$1.48 \mathrm{mgCOD} / \mathrm{mgVSS}$ and $\mathrm{N} / \mathrm{COD}=67.6 \mathrm{mgN} / \mathrm{gCOD}$ or $\mathrm{f}_{\mathrm{n}}=$ $0.10 \mathrm{mgN} / \mathrm{mgVSS}$ ). The variations observed in these ratios in this investigation seem to be mostly due to experimental error. Therefore, it seems reasonable to assign these ratio values to the $\mathrm{OHO}$ biomass and endogenous residue, which made up most of the VSS in this investigation $(>2 / 3 \mathrm{rds})$. In contrast, this is not true for the unbiodegradable particulate organics in the influent wastewater - the COD/VSS and N/ COD ratios of these organics are significantly higher and lower respectively than these ratios of the $\mathrm{OHO}$ and endogenous residue VSS (see Table 1 in Wentzel et al., 2006, Part1).

(5) An aspect only peripherally considered in this paper is the C balance over the WWTP. While the $\mathrm{C}$ balance is not important for the AS system itself, the C content of PS and WAS is important for AD. From the Van Haandel et al. (1998a,b) data set on AD of WAS, the CHON composition of the biodegradable component of the WAS was estimated from the measured VSS/COD and N/COD ratios to be $\mathrm{C}_{5667} \mathrm{H}_{7} \mathrm{O}_{2} \mathrm{~N}_{0865}$. From COD, VSS and TSS measurements and $\mathrm{C}, \mathrm{H}$ and $\mathrm{N}$ elemental composition analysis, the biodegradable component of the WAS in the author data set was measured to be $\mathrm{C}_{3.691} \mathrm{H}_{7.0} \mathrm{O}_{1.99} \mathrm{~N}_{0.503}$ and yielded a reasonable correlation between calculated and measured AD performance. A sensitivity analysis with the AD model stoichiometry showed that the gas flow and composition are not very sensitive to biodegradable organics composition for the same COD load. The CHON stoichiometry of AD of wastewater organics can be modified and applied also to ND AS to include this system in the C balance over the WWTP. This, and the feasibility of developing approximate $\mathrm{CHON}$ stoichiometric compositions for the different influent wastewater organic fractions will be explored in further research to try to close the $\mathrm{C}$ balance over the WWTP.

This research, together with that of Sötemann et al. (2005b), which showed that the steady state AD model gives very closely the same results as their dynamic simulation one, demonstrates that the mass balance-based steady state and dynamic simulation AS and AD models provide internally consistent and externally compatible elements that can be coupled to produce plantwide steady state and dynamic simulation WWTP models for the whole WWTP without changing the values of the widely accepted stoichiometric and kinetic constants included in the AS models.

\section{Acknowledgments}

This research was supported by the Water Research Commission, the National Research Foundation and the University of Cape Town and is published with their permission.

\section{References}

BATSTONE DJ, KELLER J, ANGELIDAKI I, KALYUZHNYI SV, PAVLOSTATHIS SG, ROZZI A, SANDERS WTM, SIEGRIST H and VAVILIN VA (2002) Anaerobic Digestion Model No 1 (ADM1). Scientific and Technical Report No 9, International Water Association (IWA), London, UK.

CHRISTENSEN DR and McCARTY PL (1975) Multi-process biological treatment model. $J$. WPCF 47 2652-2664.

GOSSETT JM and BELSER RL (1982) Anaerobic digestion of waste activated sludge. J. Environ. Eng. Div., ASCE 108 (EE6) 11011120.

EKAMA GA, WENTZEL MC and SÖTEMANN SW (2006a) Mass balance-based plant-wide wastewater treatment plant models - Part 2: Tracking the influent inorganic suspended solids. Water SA 32 (3) $277-286$

IZZETT HB, WENTZEL MC and EKAMA GA (1992). The Effect Of Thermophilic Heat Treatment On The Anaerobic Digestibility Of Primary Sludge. Research Report W76, Univ. of Cape Town, Dept. of Civil Eng. Rondebosch 7701, Cape, South Africa.

MARAIS GvR and EKAMA GA (1976) The activated sludge process Part 1 - Steady state behaviour. Water SA 2 (4) 163-200.

McCARTY PL (1974) Anaerobic processes. Presented at International Association of Water Pollution Research (IAWPR, now IWA) short course on Design Aspects of Biological Treatment, Birmingham, UK, 18 Sept. 1974.

McKINNEY RE (1962) Mathematics of complete mixing activated sludge. J. San. Eng. Div., ASCE 88 (SA3) 87-113.

RISTOW NE, SÖTEMANN SW, LOEWENTHAL RE, WENTZEL MC and EKAMA GA (2005) Hydrolysis of Primary Sludge Under Methanogenic, Acidogenic And Sulfate Reducing Conditions. WRC Report No. 1216/1/05, Water Research Commission, Private Bag X03, Gezina, 0031, RSA. ISBN 1-77005-290-5.

SÖTEMANN SW, RISTOW NE, WENTZEL MC and EKAMA GA (2005a) A steady state model for anaerobic digestion of sewage sludges. Water SA 31 (4) 511-527.

SÖTEMANN SW, VAN RENSBURG P, RISTOW NE, WENTZEL MC, LOEWENTHAL RE and EKAMA GA (2005b) Integrated chemical, physical and biological processes modelling Part 2 - Anaerobic digestion of sewage sludges. Water SA 31 (4) 545-568.

VAN HAANDEL AC, CATUNDA PFC and ARAUJO L (1998a) Biological sludge stabilization Part 1 - Kinetics of aerobic sludge digestion. Water SA 24 (3) 223-230.

VAN HAANDEL AC, CATUNDA PFC and ARAUJO L (1998b) Biological sludge stabilization Part 2 - Influence of the composition of waste activated sludge on anaerobic digestion. Water SA 24 (3) 231-236.

WENTZEL MC, EKAMA GA and SÖTEMANN SW (2006) Mass balance-based plant-wide wastewater treatment plant models - Part 1: Biodegradability of wastewater organics under anaerobic conditions. Water SA 32 (3) 269-276.

WRC (1984) Theory, Design and Operation of Nutrient Removal Activated Sludge Processes. Wiechers HNS (ed.), WRC Report No TT 16/84, Water Research Commission, Private Bag X03, Gezina, 0031, RSA. ISBN 0908356137.

YASUI H, SUGIMOTO M, KOMATSU K, GOEL R, LI YY and NOIKE T (2006) An approach for substrate mapping between ASM and ADM1 for sludge digestion. Proc. $1^{\text {st }}$ Int. Workshop on the IWA Anaerobic Digestion Model No 1. Lyngby - Denmark. 2-4 Sept. 73-80. 